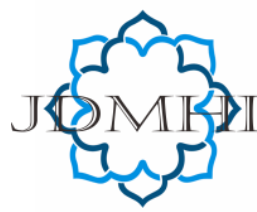

email: jdmhi@walisongo.ac.id

Journal of Digital Marketing and Halal Industry

ISSN: 2716-4810 (print) ISSN: 2716-4802 (online)

\title{
YouTuber And Googlepreneur: Review of the Contemporary Fiqh of Zakah
}

\author{
M. Sultan Mubarok, M. Taufiq Abadi \\ Institut Agama Islam Negeri Pekalongan, Indonesia
}

\section{A R T I C L E I N F O}

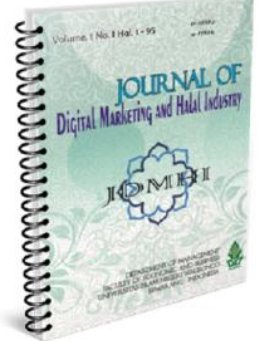

Article history:

Received 14 January 2020

Accepted 03 July 2020

Published 10 July 2020

Keywords:

Contemporary fiqh of zakat,

Zakat googlepreneur, Zakat

profession, Zakat youtuber.
A B S T R A C T

The industrial revolution 4.0 brings opportunities and challenges for zakat management institutions. YouTuber and Googlepreneur are part of the effects of changing times, which has the potential to generate revenue. The purpose of this study is to discuss Islamic jurisprudential law regarding zakat Youtuber and googlepreneur, as well as how to calculate nishab. The study shows that YouTubers and Googlepreneur are required to pay zakat because it belongs to the profession affected by zakat. The method of calculating zakat is based on three approaches, namely (a) referring to zakat of gold, silver, and trade, provided that the calculation of 85 grams of gold (20 dinars) or 595 grams of silver (200 dirhams) with a tithe content of $2.5 \%$ and time to spending once a year, (b) expressed by agricultural alms, with the provisions of aishq five ausaq (harvest $653 \mathrm{~kg}$ ), the level is $5 \%$ and issued every income or salary, (c) qyas shahbah or analogous to two things at once, with the provisions of nishab five ausaq $(653 \mathrm{~kg}$ of harvest) and released when receiving $2.5 \%$.

@2020 Journal of Digital Marketing and Halal Industry

\section{Introduction}

The industrial revolution 4.0 has led to new professions that have the potential to make large amounts of money. YouTuber and Googlepreneur are part of the new profession. This raises new questions in the study of contemporary fiqh, namely, how is the Islamic fiqh law about zakat YouTuber and googlepreneur, which are becoming promising professions today? is that profession included in the part of zakat in Islam? Or is that something new in Islam? And how to calculate the Nisab?

Al-Qur'an and Al-Sunnah, do not explain specifically about the profession of zakat (YouTuber and GooglePreneur). Likewise, mujtahid scholars such as Imam Abu Hanifa,

\footnotetext{
* Corresponding author. email: muhammad.sultan.mubarok@iainpekalongan.ac.id DOI: http://dx.doi.org/10.21580/jdmhi.2020.2.1.5034
} 
Imam Malik, Imam Shafi'i and Imam Ahmad bin Hambal did not discuss this in their works. But explicitly at the time of the Prophet Muhammad a discussion of the issue of professional zakat has been implemented, such as zakat, livestock zakat, zakat of gold, and silver (Riyadi, 2015).

The controversy about professional zakat law in Indonesia, both among Muslim communities and Muslim professionals, has not been well understood in general (Baidowi, 2018). The study that discusses income zakat is classified as new in Islamic fiqh studies (Bimasakti, 2018).

YouTuber is a term for video creators who make money by making interesting videos and then uploaded on YouTube (Rizem, 2019). YouTuber is a profession that arises due to social shifts in modern society by uploading videos of his work to YouTube (Enterprise, 2018).

YouTubers is one type of work that has emerged along with the extensive use of big data connected to the internet as a form of promising opportunity in the 4.0 industrial revolution era. In comparison, Googlepreneur is a businessman and entrepreneur who uses the facilities provided by Google to optimize products advertised to Google users (Onggo, 2008). When viewed in terms of the language googlepreneur comes from the word entrepreneur. The domain preposition shows the basis of business and entrepreneur, which means entrepreneurs.

\section{Literature Review}

YouTuber is a term for video creators who make money by making interesting videos and then uploaded on YouTube (Rizem, 2019).
YouTuber is a profession that arises due to social shifts in modern society by uploading videos of his own work to YouTube (Enterprise, 2018). YouTubers are one type of work that has emerged along with the massive use of big data connected to the internet as a form of promising opportunity in the 4.0 industrial revolution era. YouTuber is individuals, groups, to large companies that share or upload videos to your YouTube account, with a variety of unique videos. YouTuber succeeded in becoming a source of income.

Googlepreneur is a businessman and entrepreneur who uses the facilities provided by Google to optimize products advertised to Google users (Onggo, 2008). When viewed in terms of the language googlepreneur comes from the word entrepreneur. The domain preposition shows the basis of business and entrepreneur, which means entrepreneurs (Onggo, 2008).

Googlepreneur according to (Onggo, 2008), some steps can be taken to become rich by becoming Googlepreneur including (1) having products that can be purchased and can be used by consumers repeatedly (2) having products that can be in quantity in units as well as many (3) market share not individuals but corporates (4) markets may be local but can overtake international markets (5) or maybe the products of others but fulfil the characteristics as stated. (6) make the google search engine always appear in the top 5 or 10 .

The law of paying zakat for a YouTuber and Googlepreneur is mandatory by using an analogical deduction (qiyas) approach with professional zakat (income zakat). Still, some conditions must be met concerning Youtuber and GooglePreneur workers, firstly, the type of halal business. Second, making relatively much 
money. Third, it is obtained easily. Fourth, through certain expertise (Khairul Bahri et al., 2019: 70). This argument is obtained by interpreting QS. Al Baqarah verse 267 and QS. At-Taubah, verse 103, as follows:

"Believers, spend (in the way of Allah) some of the results of your good efforts and some of what we spend from the earth for you. And do not choose the bad, then you spend it on it, even though you yourself do not want to take it but with a squint to him. And know that Allah is Rich, Most Praised" (QS. Al Baqaraah: 267)

According to Masfuk Zuhdi, all types of income are subject to the obligatory zakat. Explanation of the above verse as follows, the word "ما" includes words that contain a general meaning. It can be interpreted as "anything", part of the results (any) of your good efforts (Masfuk Zuhdi, 1991: 214-215). So it can be concluded that the law of issuing zakat of a YouTuber and Googlepreneur is mandatory, with a record that the income of YouTuber and Googlepreneur exceeds the basic needs of his life and family, does not have a burden of burdensome debt, and reaches haul and nishab.

Sayyid Qutb in his interpretation entitled Fi Zhilalil Qur'an, interpreted QS Al Baqarah Verse 267 as follows, referred to in verse includes all the results of good human effort, lawful and includes all results issued by Allah SWT from the earth, both in times Rasulullah SAW or today (Baidowi, 2018). Imam alTabrani said in interpreting the verse, the intention is, "Zakatlah a good portion of what you have earned with your efforts, either through trade or carpentry, in the form of gold and silver" (Qardhawi, 2011)

Another Nash in QS. At Taubah 103:
"Take zakat of their wealth, the charity that you cleanse and purify them and pray for them. Verily, your prayers (become) peace of mind for them. And Allah is Hearing, Knowing" (QS. At Taubah: 103).

Explanation of terminology, the verse discusses the assets, not discussing where the assets were obtained (type of business), it can be concluded here that the discussion of assets that must be tackled is general, so that the form of profession of YouTuber and Googlepreneur must also be issued zakat (Baidowi, 2018).

\section{Research Method}

This research uses a qualitative approach, with library research design. This study uses data sources obtained from books, journals, and other literature that support this research. Data analysis techniques using content analysis. Content analysis is a technique used to analyze and understand the text. Content analysis can also be interpreted as an investigation technique that attempts to decipher objectively and systematically.

The naturalistic-interpretative paradigm influences qualitative research. Where researchers try to construct reality and understand its meaning so that this study is very concerned about the process, events, and authenticity, using content analysis methods must observe the phenomenon of communication, by formulating precisely what is studied. All actions must be based on these objectives. Next, choose the unit of analysis to be studied, select the object of research that is the target of the analysis.

Qualitative research content analysis (content analysis) is done by adjusting or negating the 
profession of YouTube and Googlepreneur by basing on the existing zakat laws.

\section{Result and Discussion}

The phenomenon of YouTuber and Googlepreneur in Indonesia

YouTuber is a term for video creators who make money by making interesting videos and then uploaded on YouTube. YouTuber is a profession that emerged due to the social shift of modern society by uploading videos of his own work to YouTube. YouTubers are one type of work that has emerged along with the massive use of big data connected to the internet as a form of promising opportunity in the 4.0 industrial revolution era. In comparison, Googlepreneur is a businessman and entrepreneur who uses the facilities provided by Google to optimize the products advertised to Google users. When viewed in terms of the language googlepreneur comes from the word entrepreneur. The domain preposition indicates the basis of business and entrepreneur, which means entrepreneurs.

YouTuber and Googlepreneur trends in Indonesia experience positive and significant fluctuations from year to year. This is in line with the development of the number of internet users in Indonesia, and this can be shown in the table below:

Table 1. Number of Internet Users in Indonesia in 2013-2017

\begin{tabular}{cccccc}
\hline Time & 2013 & 2014 & 2015 & 2016 & 2017 \\
\hline $\begin{array}{c}\text { Number of User } \\
\text { (Million) }\end{array}$ & 82 & 88,1 & 11,2 & 132,7 & 143,26 \\
\hline
\end{tabular}

Source: Indonesian Internet Service Provider Association (APJII, 2019), data processed

Luci Pujasari Concludes that internet users or digital natives spend $79 \%$ of their time accessing the internet every day (Luci Pujasari, 2018: 47). This change in community culture has made it an opportunity for some people to seek fortune. In Indonesia, several names are very popular with the word YouTuber, namely: Atta Halilintar, Raditya Dikha, Edho Zell, Ria Ricis, and others. Gilang and Dinda concluded that Raditya Dika "YouTuber" with the highest popularity could be seen from the number of subscribers (Dwijaya, Gilang Muhammad dan Zuliestiana, 2017). The number of subscribers is one of the main factors affecting the number of YouTubers. The amount of YouTuber income in Indonesia can be shown in the table below:

Table 2. Average Youtuber Earnings in Indonesia 2019

\begin{tabular}{llll}
\hline No & Youtuber & Subscriber & Income \\
\hline 1 & Dude Perfect & 48.568 .033 & 23 billion / month \\
2 & PewDiePie & 101.921 .404 & 18 billion / month \\
3 & Logan Paul Vlogs & 19.889 .596 & 17 billion / month
\end{tabular}




\begin{tabular}{llll}
\hline No & Youtuber & Subscriber & Income \\
\hline 4 & Atta Halilintar & 18.959 .150 & 490 million / month \\
5 & Ricis Official & 16.842 .449 & 385 million / month \\
6 & Rans Entertainment & 10.164 .747 & 375 million / month \\
7 & Official Sabyan Gambu & 5.974 .885 & 340 million / month \\
8 & Deddy Corbuzier & 5.728 .372 & 190 million / month \\
9 & Raditya Dika & 7.815 .466 & 165 million / month \\
10 & Fikrifadlu & 2.946 .495 & 140 million / month \\
\hline
\end{tabular}

Source: Youtube Adsense accessed in ruanglaptop.com, and data processed 2019

Table 3. Average Googlepreneur Income in Indonesia 2019

\begin{tabular}{lll}
\hline No & Googlepreneur & \multicolumn{1}{c}{ Income } \\
\hline 1 & Yosef Ardhi & 7,817 billion / month \\
2 & Astri Tadda & 200 million / month \\
3 & Joko Susilo & 75 million / month \\
\hline
\end{tabular}

Source: Google Adsense accessed at digital.ortizaku.com, and data processed 2019

The table above shows that the income derived from Youtuber show large numbers every month (Supratman, 2018). Googlepreneur in Indonesia has an average income of less than 70 million / month above figures exceed the compulsory Zakat nishab property if it rests on the nishab the wealth maal 93.6 grams of gold. But how does the contemporary fiqh of zakat explain this phenomenon?

\section{Overview of Contemporary Fiqh of Zakat For YouTuber and Googlepreneur}

YouTuber and GooglePreneur can be classified in the types of professional occupations. The word profession in the big Indonesian Dictionary (KBBI) has a meaning as a job that requires expertise (skills, vocational and others). Whereas according to the language of the profession comes from the Latin "profession" means promises/pledges and work, more broadly defined as what activities and anyone in an effort to meet the needs of life (living) with certain expertise. In Arabic terms, income and professional zakat are better known as "zakatu kasb al-amal wa almihan al-huraah" or zakat on work income and free profession. This title is used by (Qardhawi, 2011) in his work entitled Fiqhuz Zakah and Dr. Wahbah Az-Zuhaili in his work entitled Al Fiqhul Islami Wa Adillatuhu (Riyadi, 2015).

YouTuber and Googlepreneur are forms of business that are updated in the present, so it is not surprising if they are not mentioned normatively in Islamic law and regulations. Naturally, this issue cannot be found clearly (explicitly) in both the Qur'an and the Sunnah. In the methodology of Islamic law (ushul figh) to find solutions to legal problems that are not yet contained in the text of the Al-Quran and Al-Sunnah clearly then it can be taken in several ways, namely, the agreement of the mujtahid (ijma '), directing all abilities to think optimally to issue sharia law (ijtihad), release one law for another law because it gives the syara argument 'which requires or leaves it (Istihsan), analogical deduction (qiyas), habit (' urf), istishab, istislah, istihsun, and the benefit of the problem.

The four madzab views on the necessity of zakat youtuber and googlepreneur (income/ 
profession) differ in opinion, explained as follows: Imam Shafi'i said that income assets are not required to be zakati, even though he has similar assets that have reached nishab. However, he excluded domestic animals, where the zakat animals were not distributed along with their parent's zakat, which reached nishab. If it had not yet reached nishab, it was not obligatory for zakat (Ibnu Hazm, tt: 196). Imam Maliki is of the view that the income assets are not issued zakat except until the haul (one year), whether the assets are similar to the assets owned or not, except for the types of pets. Because people who earn income in the form of pets (not their children) and he has a similar domestic animal and has reached nishab, he must pay zakat on the whole animal when it reaches haul. And if it hasn't reached the haul, then the zakat is not required to be issued.

Imam Abu Hanifah has a different opinion, the income treasure is zakat when it reaches the haul, except if the muzzaki has the same type of property that must be issued zakat, for the zakat income, is issued at the beginning of the year on condition of reaching nishab. Thus, if muzzaki earns a little or a lot of income, even though one hour before the year (haul) of newly acquired assets, it is compulsory for him to disburse his zakat together with the same principle, in the form of gold, silver, domestic animals or other.

The difference of the three Imams in determining the income zakat can be explained as follows, Imam Shafi'i requires a nishab and takes a year to issue income zakat, likewise, Imam Mālik does not require issuing zakat on income except after reaching a year on condition that it reaches nishab. As for Imam Abu Hanifah requires a full year of ownership of income assets, except if the asset already has one nishab, then the income zakat must be issued even though there is not yet one year, so it is issued at the beginning of the year. While in the literature, Imam Hambali's opinion was not found on the issue of professional zakat (Khairul Bahri et al, 2019: 82).

Professional zakat in contemporary fiqh thinking by looking at the instinbat method used can be explained as follows, Yusuf Qardawi Utilizing at-Turuq al-Lugawiyah namely lafadz 'amm contained in the AlBaqarah verse 267, in lafadz "mā kasabtum", whereas in lafadz "mā kasabtum" at-Turūq alMa'nawiyah, he uses the qiyas method, by removing the professional zakat with gold and silver zakat, by referring to the illat between the two as equal, namely the name "(a developing and economically valuable asset). Didin used at-Turuq al Lugawiyah and atturuq al-Ma'nawiyah. The three propositions of al-Qur'an are used by Didin in determining professional zakat, such as lafadz al-Amwāl, mā kasabtum including lafadz 'amm. In essence explains that all the good professions that already existed in the time of the Prophet and the profession today are required to issue zakat. Didin also used at-turuq al-Ma'nawiyah to use the Al Syabāh qiyās method in determining 'illat when Didin eliminated the profession of zakat with two forms of zakat at once, namely for his nishab to be sliced into agricultural zakat, while his zakat was sliced away at the zakat of gold and silver because of his zakat. there are similarities between the two.

In contrast to Jalal, he rejected the use of qiyas in determining the profession zakat law. According to Jalal, there is no use of reason (ratio) in matters of worship. So that his ijtihad is only fixed in the Qur'an and Hadith. 
The evidence used by Jalal in surah al-Anfal verse 41 is lafadz "musytarak" (at-Turuq alLugawiyah) contained in lafaz "ganimtum". From Jalal's interpretation, that lafadz "ganimtum" does not only mean war booty assets, but also means income from a profession that is obligatory to pay zakat, if it exceeds the basic needs of one fifth (khumus) (Habibah, 2015).

Viewed from a positive legal aspect in Indonesia, the obligation to dispense zakat for strangers who work as youtubers or googlepreneur is regulated in (UndangUndang No. 23 Tahun 2011 Tentang Pengelolaan Zakat, 2011) article 4 point h. in the Act stated that "zakat mal seized several types of assets, certain: (a) gold, silver and other precious metals, (b) money and other securities, (c) commerce, (d) agriculture, plantation and forestry, (e) animal husbandry and fisheries, (f) mining, (g) industry, (h) income and services, (i) rikaz. Revenues and services here can be used based on the obligation of zakat youtuber and googlepreneur.

\section{Nishab Zakat Youtuber and Googlepreneur and how to calculate it}

Nishab zakat is a limitation (a passing grade) of assets that must be zakat or not must be zakat (Setiawan Budi, 2009: 54). Because YouTuber and Googlepreneur are new types of professions in Indonesia, then to calculate the ratio using the analogical deduction method (qiyas) to other zakat points that already have calculations that already have legal provisions. There are three approaches in determining the calculation and the amount of zakat for YouTuber and GooglePreneur namely, (a) it is altered in gold, silver and trade zakat, (b) it is pronounced on agricultural zakat, (c) Qiyas shahbah or analogous to two things at once. If you use the first approach (zakat of gold, silver and trade), then the threshold of 85 grams of gold (20 dinars) with zakat content of $2.5 \%$ and time to issue once a year. If using the silver standard, then the threshold of 595 grams of silver (200 dirhams), the amount of zakat of $2.5 \%$ is issued once a year. The second approach (zakat of agriculture) is nishab 5 ausaq (653 kg of harvest), the level is 5\% and is spent every time earning / salary. The third approach (qiyas syabah), namely on agricultural zakat (nishab) and on gold and silver zakat (levels), where the nishab is 5 ausaq (653 kg of harvest) and is issued when receiving it at a rate of 2.5\% (Puskas Baznas, 2017 : 8-9).

The author tends to use positive legal regulations that have been elaborated (Kementerian Agama, 2014) namely Regulation of the Minister of Religion of the Republic of Indonesia Number 52 of 2014 concerning the terms and procedures for calculating zakat mal and zakat fitrah as well as utilizing zakat for productive business. In Article 26 it is stated that the zakat nishab is worth $653 \mathrm{~kg}$ of grain or $524 \mathrm{~kg}$ of rice and the income and service zakat content is $2.5 \%$.

\section{Conclusion}

YouTuber and Googlepreneur are required to pay zakat for the income he has earned, although this profession is relatively new in this millennial era, but has relatively large earning potential. There are 3 approaches that can be used to calculate the amount of zakat of a youtuber and googlepreneur, namely (a) zakah on gold, silver and trade zakat, with the provisions of the threshold of 85 grams of gold (20 dinars) or 595 grams of silver (200 dirhams) with zakat levels of $2,5 \%$ and the 
time spent once a year, (b) is narrated on the zakat of agriculture, with the provisions of the nishab of 5 ausaq (653 $\mathrm{kg}$ of harvest), the level is $5 \%$ and is spent every time earning / salary, (c) Qiyas shahbah or analogous to two things at the same time, with the provisions of the rate of 5 ausaq (653 kg of harvest) and issued when receiving it at a rate of $2.5 \%$. This third alternative is more recommended because it is in accordance with Ministry of Religion regulation number 52 of 2014.

\section{Recommendation}

Optimizing the potential of zakat in the industrial revolution 4.0, the authors suggest that the government and related ministries and academics be more intensive in terms of opening a mindset of awareness of zakat and socializing about the types of zakat the latest adapted to the progress and changing times.

\section{References}

APJII. (2019). Mengawali Integritas Era Digital 2019. In Buletin Assosisasi Penyelenggara Jasa Internet Indonesia (APJII) (Edisi 33).

Baidowi, I. (2018). Zakat Profesi (Zakat Penghasilan). Tazkiya: Jurnal Keislaman, Kemasyarakatan \& Kebudayaan, 19(1), 41.

Bimasakti, M. A. (2018). Meninjau zakat penghasilan pada fatwa MUI No. 3 Tahun 2003 Dan Ijtihad Yusuf Qardhawy. Jurnal Hukum Islam, 2(1).

Dwijaya, Gilang Muhammad dan Zuliestiana, D. A. (2017). Analisis Positioning Youtuber Indonesia Berdasarkan
Persepsi Penonton Youtube Dengan Menggunakan Metode Perceptual Mapping (studi Pada Kategori Entertaiment Dengan Konten Berbasis Vlog). Proceeding of Management, 4.

Enterprise, J. (2018). Kitab Youtuber. PT Elex Media Computindo.

Habibah, S. (2015). Zakat Profesi Dalam Pemikiran Fikih Kontemporer Studi Perspektif Ushul Fikih. Az Zarqa', 7(1), 164-165.

Kementerian Agama. (2014). Peraturan Menteri Agama Republik Indonesia Nomor 52 tahun 2014 tentang Syarat dan tata cara penghitungan zakat mal dan zakat fitrah seta pendayagunaan zakat untuk usaha produktif.

Onggo, B. J. (2008). Googlepreneur. Grammedia.

Qardhawi, Y. (2011). Hukum Zakat: Studi Komparatif Mengenai Status dan Filsafat Zakat Berdasarkan Al-Qur'an dan Hadis (D. Diterjemahkan oleh: Salman Harun (ed.)). Pustaka Litera Antar Nusa.

Riyadi, F. (2015). Kontrovesi Zakat Profesi Perspektif Ulama Kontemporer. Ziswaf: Jurnal Zakat Wakaf, 2(1), 109.

Rizem, A. (2019). Cuss!!! Ke Luar Negeri Cuma Modal Hoby. Laksana.

Supratman, L. (2018). Penggunaan Media Sosial oleh Digital Native. Jurnal Ilmu Komunikasi, 15(1), 47-60.

Undang-undang No. 23 Tahun 2011 tentang pengelolaan zakat. (2011). 